\title{
Gas chromatography mass spectrometry analysis and larvicidal activity of leaf essential oil extract of Leucas aspera against dengue, malaria and filariasis vectors
}

\author{
Devan Elumalai ${ }^{1}$, Manikandan Kayalvizhi ${ }^{1}$, Patheri Kunil Kaleena ${ }^{2 *}$, Anandhan Vignesh ${ }^{3}$
} and Maduraiveeran Hemavathi ${ }^{4}$

\begin{abstract}
Background: Insect-transmitted diseases cause high morbidity but they also include deadly diseases that cause high mortality rates among infected individuals. Several mosquito species including Aedes aegypti, Anopheles stephensi, and Culex quinquefasciatus are vectors. Ae. aegypti, a vector of yellow fever, dengue, and chikungunya is widely distributed in the tropical and subtropical zones. An. stephensi is the primary vector of malaria in India and other west Asian countries. C. quinquefasciatus is a vector of lymphatic filariasis and it is widely distributed tropical diseases with around 120 million people infected worldwide.

Results: In the view of an increasing interest in developing plant-derived insecticides as an alternative to chemical insecticides, this study was undertaken to assess the larvicidal potential of essential oil extracted from Leucas aspera leaves against three medically important species of mosquito vectors, Ae. aegypti, An. stephensi, and C. quinquefasciatus. The oil extract was found to be potent against Ae. Aegypti $\mathrm{LC}_{50}$ and $\mathrm{LC}_{90}$ (lethal concentration LC) value of $15.59 \mathrm{ppm}$ and $46.77 \mathrm{ppm}$ when compared to An. stephensi (17.10 ppm and $51.20 \mathrm{ppm}$ ) and C. quinquefasciatus with $\mathrm{LC}_{50}$ and $\mathrm{LC}_{90}$ (16.19 ppm and $47.79 \mathrm{ppm}$ ) respectively. Gas chromatography mass spectrometry analysis of the essential oil extract of L. aspera was done to identify the major phytocompounds.
\end{abstract}

Conclusion: The results showed that the oil extract of $L$. aspera and its effective constituents can be considered as potent source for the production of natural larvicides.

Keywords: Vector control, L. aspera, GC-MS, Ae. aegypti, An. stephensi and C. quinquefasciatus

\section{Background}

Mosquitoes are one of the most medically significant vectors, and they transmits parasites and pathogens, which continue to have devastating impact on human beings; the vector-borne disease caused by mosquitoes are one of the major health problems in many countries. Malaria, dengue, yellow fever, and filariasis are few of the deadly disease spread by mosquitoes (Maheswaran, Kingsley, \& Ignacimuthu, 2008). The mosquito is the principal vector

\footnotetext{
* Correspondence: drpkklab@gmail.com

${ }^{2}$ Department of Zoology, Presidency College (Autonomous), Chennai, Tamil Nadu 600 005, India

Full list of author information is available at the end of the article
}

of the vector-borne disease affecting human beings and other animals; several mosquito species including Aedes aegypti, Anopheles stephensi, and Culex quinquefasciatus are vectors for the pathogens of various diseases (Karthikeyan, Sivakumar, Aishwarya, \& Mohanasundram, 2012).

An. stephensi (Liston) is the primary vector of malaria in India and other West Asian countries; malaria remains one of the most prevalent diseases in the tropical world. With 200 million to 450 million infections annually worldwide, it causes up to 2.7 million deaths (World Health Organization, 2010).

C. quinquefasciatus (Say.) acts as a vector for filariasis in India. Lymphatic filariasis caused by Wuchereria 
bancrofti and transmitted by mosquito C. quinquefasciatus is found to be more endemic in the Indian subcontinent. It is reported that C. quinquefasciatus infects more than 100 million individuals worldwide annually (Govindarajan, Mathivanan, Elumalai, Krishnappa, \& Anandan, 2011).

The control of mosquito larvae worldwide depends primarily on continued applications of synthetic insecticides including organophosphates and chlorinated hydrocarbons (e.g., DDT); however, heavy wide use of these insecticides has caused several environmental and health concerons (Chen, Chao, Ligang, \& Zhi, 2013).

Botanical pesticides have the advantage of providing novel modes of actions against insects that can reduce the risk of cross resistance as well as offering new designs for specific molecule targets. During the screening program for new agrochemicals from Chinese medical herbs and wild plants, essential oil of Ageratum conyzoides L. aerial parts at flowering stage was found to possess strong insecticidal toxicity against the Asian tiger mosquito Aedes albopictus (Liu \& Liu, 2014).

Essential oils play important role in controlling several mosquito species. In general, essential oils from plants have been considered important natural resources to act as insecticides (Gbolade, Dyedele, Sosan, Adewayin, \& Soylea, 2012); they are effective, environmentally friendly, and easily biodegradable in nature. It is suggested that many compounds derived from various essential oils can cause toxic activity against mosquito species (Bhat \& Kempraj, 2009).

The use of herbal products is one of the best alternatives for mosquito control. Many researchers have been reported on the larvicidal properties of plant essential oils against Anopheles mosquitoes. Essential oils extracted from Azadirachta indica (Okumu, Knols, \& Fillinger, 2007) and leaves and rhizomes of Curcuma longa (Molodchik, 2013). Plectranthus amboinicus, Zanthoxylum aratum, Eucalyptus tereticornis, and Tagetes patula demonstrated larvicidal activity against Anopheles stephensi (Dharmagadda, Naik, Mittal, \& Asudevan, 2014). Larvicidal activity of essential oils from Blumea mollis and Zingifer officinalis (Pushpanathan, Jebanesan, \& Govindarajan, 2008) has been reported against $C$. quinquefasciatus.

Larvicidal activity of essential oils from Melaleuca leucadendron, Litsea cubeba and Listea salicifolia, Ocimum suave, and O. kilimandshricum (Kweka, Mosha, Lowassa, Mahande, Kitau, Matowo, Mahande, Massenga, Tenu, Feston, Lyatuu, Mboya, Meneme, Chuwa, \& Temu, 2008) have been reported against Anopheles arabiensis, An. gambiae, and C. quinquefasciatus. Larvicidal activity of essential oils from Zanthoxylum armatum (Tiwary, Naik, Tewary, Mittal, \& Yadav, 2007) and Ocimum canum (Singh, Kumari, \& Chauhan, 2003) have been reported against C. quinquefasciatus, Ae. aegypti, and $A n$. stephensi. Essential oils derived from various plants not only exhibit inhibitory activity against bacteria, fungi, and termites but also show strong mosquito repellent larvicidal activities; the present study was aimed to assess the larvicidal and knockdown activities of the essential oils from various plants against $C$. quinquefasciatus, Ae. aegypti, and An. stephensi (Cheng, Liu, Tsai, Chen, \& Chang, 2004).

Leucas aspera (Wild.) Link of the family Lamiaceae is an annual, branched herb that commonly grows in grassland. It is distributed throughout India from the Himalaya to Ceylon. In traditional medicine, this plant is used as an antipyretic and insecticide, and diverse biological activities such as antioxidant, antimicrobial, hepatoprotective, antinociceptive cytotoxic, and anthelminthic have been reported. The major volatile constituents are alpha-farnesene, alpha-thujene, and menthol leaves, while namely propionate and isoamyl propionate from flowers of $L$. aspera have been reported from India (Mangathayatu, Amitabha, Rajeev, \& Kaushik, 2006). In another report from Nepal, the main constituents from the essential oil of aerial parts of $L$. aspera were identified as1-octen-3-ol, caryophyllene, and caryophyllene oxide; the essential oil of the seeds of $L$. aspera has larvicidal properties against the mosquito Aedes aegypti (Joshi 2013). In the present study, the larvicidal activity of the oil extract of $L$. aspera leaves were investigated against Ae. aegypti, An. stephensi, and C. quinquefasciatus.

\section{Methods}

\section{Collection of plant}

Leucas aspera plant leaves were collected from Kancheepuram District, Tamil Nadu, India during the month of January, 2016. L. aspera (Fig. 1) was identified by (Voucher. No. 2110; Flora of South India by G.S. Gamble-

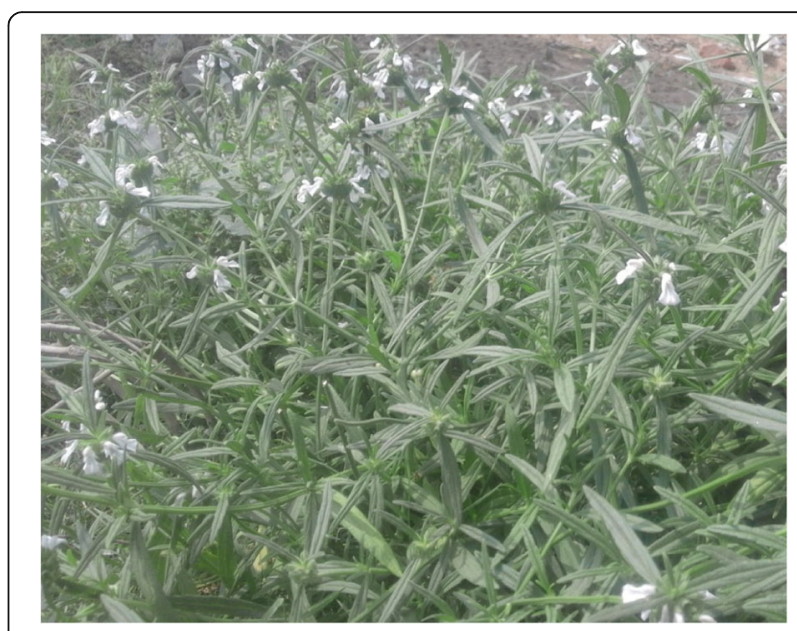

Fig. 1 Leucas aspera 
Volume-II) Prof. P. Jayaraman, Plant Anatomy Research Centre (PARC), West Tambaram, Chennai-600045.

\section{Distillation of essential oils}

Fresh leaves of L. aspera were subjected to hydrodistillation using a modified clevenger type apparatus for $3 \mathrm{~h}$ (Cheng, Liu, Tsai, Chen, \& Chang, 2004). The yield was averaged over four experiments and calculated according to dry weight of the plant material. Essential oil was stored in an air-tight container prior to analysis by gas chromatography mass spectrometry (GC-MS).

\section{Gas chromatography mass spectrometry analysis}

The composition of the essential oil was determined using an Agilent 7890 GC-MS instrument. Oxygen-free nitrogen was used as a carrier gas and hydrogen was used for the flame. The GC conditions used were as follows: capillary column: fused silica (polydimethylsiloxane $0.25 \mu \mathrm{m}$ film thickness); temperature program: $70{ }^{\circ} \mathrm{C}$ $\left(2 \min ^{1}\right), 70-230{ }^{\circ} \mathrm{C}\left(3 \min ^{1}\right), 230-240{ }^{\circ} \mathrm{C}\left(5 \min ^{1}\right)$, $270{ }^{\circ} \mathrm{C}\left(5 \mathrm{~min}^{1}\right)$; carrier gas, held at 5 bar, linear velocity of $20 \mathrm{~cm} \mathrm{~min}{ }^{1}$; injection port splitless at $250{ }^{\circ} \mathrm{C}$; injection volume, $0.1 \mu \mathrm{L}$. The MS conditions were as follows: ionization Elat $70 \mathrm{eV} ; \mathrm{m} / z$ range, $30-300{ }^{\circ} \mathrm{C}$; scan rate $1 \mathrm{~s}^{1}$; ionization chamber at $180{ }^{\circ} \mathrm{C}$; and transfer line at $280{ }^{\circ} \mathrm{C}$. The identification of the essential oil constituents was done based on a comparison of their retention times and these constituents were further identified and authenticated using mass spectrophotometry (MS) data compared to the NIST mass spectral library.

\section{Selection and identification of mosquito species}

The important vector species of mosquitoes such as Ae. aegypti, An. stephensi, and C. quinquefasciatus were selected and identified in the Zonal Entomological Research Centre, Vellore, Tamil Nadu, India. An. stephensi is vector of malaria in India and larvae of these species are generally found in distinctly different habitat. Ae. aegypti is a vector for transmitting several tropical fevers such as dengue fever, chikungunya, yellow fever, and other diseases. C. quinquefasciatus (Say.) acts as a vector for filariasis in India. C. quinquefasciatus is the vector of West Nile which causes encephalitis or meningitis affecting the brain tissue resulting in permanent neurological damage.

\section{Bioassays and larval mortality}

Fourth instar larvae of Ae. aegypti, An. stephensi, and C. quinquefasciatus were exposed to test concentrations of $5,10,15,20$, and 25 ppm of essential oil for $24 \mathrm{~h}$ according to standard methods described by the World Health Organization (WHO, 1981). In the control setup, ethanol was applied in the water (1\%) and the numbers of dead larvae were counted after $24 \mathrm{~h}$ of exposure and the percentage of mortality were analyzed from the average of five replicates. The lethal concentration $\left(\mathrm{LC}_{50}\right.$ and $\mathrm{LC}_{90}$ ) were calculated by probit analysis (Finney, 1971).

\section{Statistical analysis}

The average larval mortality data were subjected to probit analysis for calculating $\mathrm{LC}_{50}, \mathrm{LC}_{90}$, and other

Table 1 Larvicidal activity of oil extract of Leucas aspera against malaria, dengue, and filariasis vectors

\begin{tabular}{|c|c|c|c|c|c|}
\hline Species & Concentration (ppm) & 24 h \% Mortality & $\mathrm{LC}_{50}(\mathrm{UCL}-\mathrm{LCL})(\mathrm{ppm})$ & $\mathrm{LC}_{90}(\mathrm{UCL}-\mathrm{LCL})(\mathrm{ppm})$ & $r^{2}$ \\
\hline \multirow[t]{5}{*}{ An. stephensi } & 50 & 100 & $17.10(20.56-14.21)$ & $51.20(58.49-47.19)$ & 0.983 \\
\hline & 30 & 82 & & & \\
\hline & 30 & 70 & & & \\
\hline & 20 & 56 & & & \\
\hline & 10 & 43 & & & \\
\hline \multirow[t]{5}{*}{ Ae. aegypti } & 50 & 100 & 15.59 (18.74-13.14) & 46.77 (49.90-42.09) & 0.944 \\
\hline & 30 & 93 & & & \\
\hline & 30 & 74 & & & \\
\hline & 20 & 63 & & & \\
\hline & 10 & 49 & & & \\
\hline \multirow[t]{5}{*}{ C. quinquefasciatus } & 50 & 100 & 16.19 (19.70-12.18) & 47.79 (45.91-40.05) & 0.942 \\
\hline & 30 & 92 & & & \\
\hline & 30 & 71 & & & \\
\hline & 20 & 60 & & & \\
\hline & 10 & 44 & & & \\
\hline
\end{tabular}


statistics at $95 \%$ confidence limits of upper confidence limit and lower confidence limit and Chi-square values were calculated using the SPSS 11.5 (Statistical Package of Social Sciences) software. Results with $P<0.05$ were considered to be statistically significant.

\section{Result and discussion}

The regression equations of the oil extract against fourth instar larvae of Ae. aegypti, An. stephensi, and C. quinquefasciatus after $24 \mathrm{~h}$ of exposure is represented in (Table 1). The results clearly indicate that the leaf oil extracts of $L$. aspera at very low concentration was toxic against all the three mosquito species tested. The oil extract was found to be potent against $A$ e. aegypti with $\mathrm{LC}_{50}$ and $\mathrm{LC}_{90}$ value of $15.59 \mathrm{ppm}$ and $46.77 \mathrm{ppm}$ when compared to An. stephensi (17.10 ppm and $51.20 \mathrm{ppm}$ ) and C. quinquefasciatus with
$\mathrm{LC}_{50}$ and $\mathrm{LC}_{90}(16.19 \mathrm{ppm}$ and $47.79 \mathrm{ppm})$ respectively. The essential oils were found to be relatively more toxic to the larvae of mosquitoes. Earlier studies involving the essential oils obtained from various plants, viz. Ocimum lamiifolium, Chenopodium ambrosioides, Mentha spicata, Eucalyptus globules, and Azadirachta indica (neem), showed larvicidal activity against the larvae of the Anopheles gambiae mosquito (Massebo, Tadesse, Bekele, Balkew, \& Michael, 2009). The use of plant essential oils in insect control is an alternative pest control method for minimizing the noxious effects of some pesticides compounds on the environment (Fatope, Ibrahim, \& Takeda, 1993).

The results of GC-MS characterization of L. aspera are presented in (Table 2). In the essential oil of $L$. aspera, 30 components are present. Some major components observed are Longifolene, 1,4,7,-caryophyllene

Table 2 Gas chromatography mass spectrometry of essential oil from the leaves of L. aspera

\begin{tabular}{|c|c|c|c|c|c|}
\hline S. No & RT & Name of the compound & Molecular formula & Mol. weight (g/mol) & Peak area \\
\hline 1 & 9.767 & 2H-1-1Benzopyran & $\mathrm{C}_{13} \mathrm{H}_{22} \mathrm{O}$ & 194.31 & 0.06 \\
\hline 2 & 10.55 & Alpha-Cubebene & $\mathrm{C}_{15} \mathrm{H}_{24}$ & 204.35 & 0.04 \\
\hline 3 & 11.13 & Cyclohexane, 1-ethenyl-1-methyl & $\mathrm{C}_{12} \mathrm{H}_{20}$ & 164.28 & 1.40 \\
\hline 4 & 11.36 & Isocaryophillene & $\mathrm{C}_{15} \mathrm{H}_{24}$ & 204.35 & 1.63 \\
\hline 5 & 11.59 & Longifolene & $\mathrm{C}_{15} \mathrm{H}_{24}$ & 204.36 & 42.69 \\
\hline 6 & 11.69 & Bicyclo & $\mathrm{C}_{9} \mathrm{H}_{16}$ & 124.22 & 0.63 \\
\hline 7 & 11.98 & 1,4,7,-Cyclooundecatriene & $\mathrm{C}_{15} \mathrm{H}_{24}$ & 204.35 & 6.19 \\
\hline 8 & 12.23 & 1H-Cyclopropa(a) naphthalene & $\mathrm{C}_{11} \mathrm{H}_{8}$ & 140.181 & 1.34 \\
\hline 9 & 12.35 & Spiro & $\mathrm{C}_{9} \mathrm{H}_{4} \mathrm{O}$ & 138.20 & 0.84 \\
\hline 10 & 12.39 & Naphthalene & $\mathrm{C}_{10} \mathrm{H}_{8}$ & 138.17 & 2.62 \\
\hline 11 & 13.19 & Caryophyllene oxide & $\mathrm{C}_{15} \mathrm{H}_{24}$ & 204.36 & 0.31 \\
\hline 12 & 13.74 & Beta-Santalol & $\mathrm{C}_{15} \mathrm{H}_{24} \mathrm{O}$ & 220.35 & 0.14 \\
\hline 13 & 14.05 & Magastigma-4,6(E),8(Z)-triene & $\mathrm{C}_{13} \mathrm{H}_{20}$ & 176.29 & 0.21 \\
\hline 14 & 14.11 & Alloaromadendrene oxide-(1) & $\mathrm{C}_{15} \mathrm{H}_{24} \mathrm{O}$ & 220.35 & 0.17 \\
\hline 15 & 14.51 & 8-Heptadecene & $\mathrm{C}_{17} \mathrm{H}_{34}$ & 238.45 & 0.90 \\
\hline 16 & 14.93 & Pentadecanal & $\mathrm{C}_{15} \mathrm{H}_{30} \mathrm{O}$ & 226.39 & 0.26 \\
\hline 17 & 16.30 & 2-Pentadecanone,6,10,14-trimethyl & $\mathrm{C}_{18} \mathrm{H}_{36}$ & 268.47 & 0.49 \\
\hline 18 & 16.60 & 10,10-Dimethyl-2,6-dimethylenebicy & $\mathrm{C}_{15} \mathrm{H}_{24} \mathrm{O}$ & 220.35 & 0.31 \\
\hline 19 & 16.76 & 13-Tetradece-11-yn-1-ol & $\mathrm{C}_{14} \mathrm{H}_{24} \mathrm{O}$ & 208.33 & 0.15 \\
\hline 20 & 16.82 & 3-Tetradecen-5-yne & $\mathrm{C}_{14} \mathrm{H}_{24}$ & 192.34 & 0.49 \\
\hline 21 & 17.04 & Octadecanal & $\mathrm{C}_{18} \mathrm{H}_{38} \mathrm{O}$ & 270.49 & 0.29 \\
\hline 22 & 17.59 & n-Hexadecanoic acid & $\mathrm{C}_{16} \mathrm{H}_{32} \mathrm{O}_{2}$ & 256.42 & 4.68 \\
\hline 23 & 17.77 & 5-Eicosene & $\mathrm{C}_{20} \mathrm{H}_{40}$ & 280.53 & 0.38 \\
\hline 24 & 17.81 & 13-Ctadecadien-1-ol & $\mathrm{C}_{18} \mathrm{H}_{34} \mathrm{O}$ & 266.46 & 0.41 \\
\hline 25 & 19.59 & 1-Docosene & $\mathrm{C}_{22} \mathrm{H}_{44}$ & 308.58 & 0.41 \\
\hline 26 & 20.50 & Heptacosane,1-chloro & $\mathrm{C}_{27} \mathrm{H}_{56}$ & 380.73 & 4.33 \\
\hline 27 & 22.12 & Octadecane & $\mathrm{C}_{18} \mathrm{H}_{38}$ & 254.44 & 0.11 \\
\hline 28 & 22.53 & Phytol & $\mathrm{C}_{20} \mathrm{H}_{40} \mathrm{O}$ & 296.53 & 1.11 \\
\hline 29 & 23.62 & Heptacosane & $\mathrm{C}_{26} \mathrm{H}_{54}$ & 366.70 & 1.08 \\
\hline 30 & 22.53 & Tetracosane & $\mathrm{C}_{24} \mathrm{H}_{50}$ & 338.65 & 0.54 \\
\hline
\end{tabular}


Table 3 Activity of phyto-components identified in medicine of essential oil from the leaves of L. aspera

\begin{tabular}{|c|c|c|}
\hline SI. No & Name of the compound & Compound medicinal activities \\
\hline 1 & Alpha-Cubebene & $\begin{array}{l}\text { Antimicrobial activity, antioxidants, anti-inflammatory, } \\
\text { anti-cancer }\end{array}$ \\
\hline 2 & Isocaryophillene & $\begin{array}{l}\text { Anti-inflammatory agents that are non-steroidal in nature. } \\
\text { In addition to anti-inflammatory actions, they have analgesic, } \\
\text { antipyretic, and platelet-inhibitory actions. }\end{array}$ \\
\hline 3 & Longifolene & The antitumor activity of compounds \\
\hline 4 & Spiro & $\begin{array}{l}\text { Microbial infections like cancer and tubercular, viral, HIV, } \\
\text { bacterial, and fungal infections }\end{array}$ \\
\hline 5 & Naphthalene & The antimicrobial and antifungal activity \\
\hline 6 & Caryophyllene oxide & $\begin{array}{l}\text { Antiedemic, antifeedant, anti-inflammatory, antitumor, } \\
\text { calcium antagonist, fungicide, insecticide, pesticide }\end{array}$ \\
\hline 7 & 8-Heptadecene & $\begin{array}{l}\text { Pulmonary edema, irritation, tetany, diarrhea, anemia, } \\
\text { respiratory failure }\end{array}$ \\
\hline 8 & $\begin{array}{l}\text { Pentadecanone,6,10, } \\
\text { 14-trimethyl }\end{array}$ & Food additives and flavoring agents \\
\hline 9 & Phytol & Antinociceptive activity and antioxidant activity \\
\hline 10 & 5-Eicosene & Anticancer activity and ntibacterial activity \\
\hline
\end{tabular}

oxide, 1,6,-hexadecanoic acid, 8-heptadecene, naphthalene, heptacosane,1-chloro, phytol, 5-eicosene, IH-Cyclopropa naphthalene, pentadecanal, etc. GC-MS analysis shows the presence of 30 components (Table 3, Fig. 2). The essential oil from the leaf extract was found to be potent against Ae. aegypti when compared to An. stephensi and C. quinquefasciatus. Extracts of Lantana aculeata against Plutella xylostells and Spodoptera litura larvae showed antifeeding and repellant effect on tea mosquito bug (Deka \& Handique, 1998). Essential oil of Ocimum americanus and Ocimum ratissium contains Caryophyllene as main constituent which possessed larvicidal activity against Ae. aegypti (Cavalcanti, Demorais, Lima, \& Santana, 2004).

Major constituents from the Tagetes patella essential oil such as limonene, $\beta$-ocimene, and $\beta$-caryophyllene

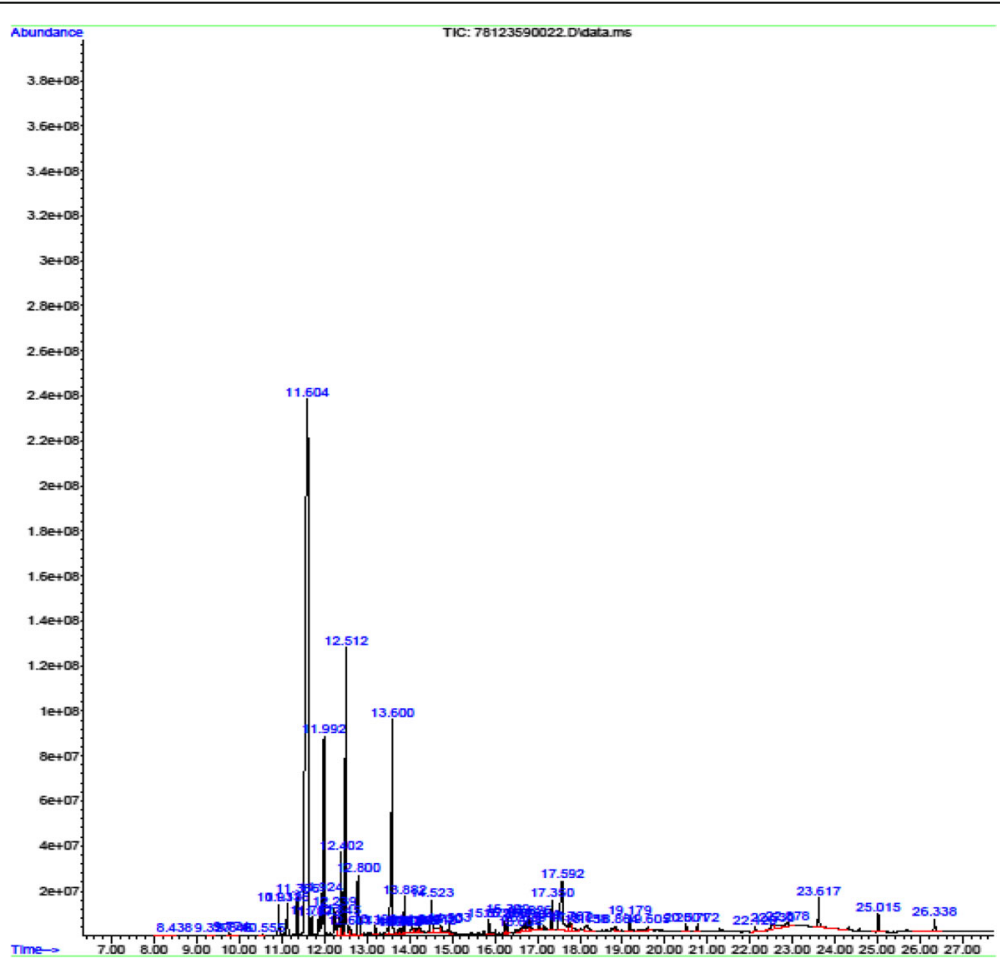

Fig. 2 GC-MS analysis of oil leaf extract of L. aspera 
possessed potent larvicidal activity (Rana \& Rana, 2012). Similar compound such as limonene and $\beta$-caryophyllene present in L. aspera may be responsible for the potent larvicidal activity; these phytocompounds may be responsible for ecdysal failure and mortality (Hemalatha, Elumalai, Vignesh, Murugesan, \& Kaleena, 2014). Besides toxic and repellent properties, essential oils have been shown to have a pronounced effect on the developmental period, growth, adult emergence, fecundity, fertility, and egg hatching of insects (Elango, Rahuman, Kamaraj, Zahir, \& Bagavan, 2010).

All terpenoids, alcohols, ketones, and carboxylic esters showed toxicity to mosquito species. Monoterpene alcohols have been reported to be toxic against mosquito species Tiwary, Naik, Tewary, Mittal and Yadav (2007) reported larvicidal activity of the essential oil extracted from the seeds of Zanthoxylum armatum against three species of mosquito vectors, Ae. aegypti, An. stephensi, and C. quinquefasciatus. Sutthanont, Choochote, Tuetun, Junkum, Jitpakdi and Chaithong (2010)) investigated the chemical compositions and larvicidal potential of Citrus hystrix, Citrus reticulate, Zingiber zerumbet, Kaempferia galanya, and Syzygium aromaticum against mosquito vectors. They suggested the use of these essential oils from edible herbs as a potentially alternative source for developing novel larvicides to be used in controlling vectors of mosquito-borne diseases. Active compounds of $L$. aspera oil extracts may be responsible for the larvicidal activity. It is evident from the present study that plant oil extracts might have promising larvicidal efficacy and could be useful in producing newer, safer, and more effective natural compounds as larvicides.

\section{Conclusion}

Plant products are emerging as a potential source for mosquito control. From the present study, it is evident that the essential oil leaf extracts of $L$. aspera have promising larvicidal efficacy. Leaf oil extracts of the plant could be used in stagnant water bodies, which are the breeding grounds for the mosquitoes. The mode of action and larvicidal efficiency of the L. aspera oil extract under the field conditions should be scrutinized and determined. Besides, further investigation regarding the effect on non-target organism is extremely important and imperative in the near future.

\section{Abbreviations}

BHC: Benzene hexa chloride; DDT: Dichloro diphenyl trichloroethane; LC: Lethal concentration; MS: Mass spectrophotometry; PARC: Plant anatomy research center; SPSS: Statistical package of social sciences; WHO: World health organization

\section{Acknowledgements}

We also thanks to The Principal and PG. Department of Zoology, Pachaiyappas College for Men, Kancheepuram, Tamil Nadu, and IIT Madras, Chennai, India-600025.
Funding

Not applicable.

Availability of data and materials

The datasets generated and analyzed during the current study are available from the corresponding author on reasonable request.

\section{Authors' contributions}

The work was framed and executed by DE. DE and MK supervised the first author. The manuscript edition (calculation and language) was done by PKK and DE. AV and MK served as sample collectors during the experimental period. All authors read and approved the final manuscript.

\section{Ethics approval}

We declare that we do not need an ethics approval regarding our work on the mosquito control.

Consent for publication

Not applicable.

\section{Competing interests}

The authors declare that they have no competing interests.

\section{Publisher's Note}

Springer Nature remains neutral with regard to jurisdictional claims in published maps and institutional affiliations.

\section{Author details}

${ }^{1}$ Department of Zoology, Pachaiyappas College For Men, Kanchipuram, Tamil Nadu 631 501, India. ²Department of Zoology, Presidency College

(Autonomous), Chennai, Tamil Nadu 600 005, India. 'ㄹepartment of Botany, Pachaiyappas College For Men, Kanchipuram, Tamil Nadu 631 501, India.

${ }^{4}$ Department of Zoology, Pachaiyappas College For Women, Kanchipuram,

Tamil Nadu 631 501, India.

Received: 12 March 2018 Accepted: 7 November 2018

Published online: 23 November 2018

\section{References}

Bhat, S. K., \& Kempraj, V. (2009). Essential oil composition and larvicidal activity of Clinopodium gracile (Matsum) aerial parts against the Aedes albopictus mosquito. Tropical Journal of Pharmacutical Research, 1956-5996.

Cavalcanti, E. S. B., Demorais, S. M., Lima, M. A. A., \& Santana, E. W. P. (2004). Larvicidal activity of oils from Barazitian plants against $A$. aegypti L. Mem Inst Oswaldo Rio de Janeiro, 99155-99154.

Chen, Chao Liu, Ligang Zhou \& Zhi Long Liu. (2013). Essential oil composition and larvicidal activity of Clinopodium gracile (Matsum) aerial parts against the Aedes albopictus mosquito. Tropical Journal of Pharmacutical Research, 15965996.

Cheng, S. S., Liu, J. Y., Tsai, K. H., Chen, W. J., \& Chang, S. T. (2004). Chemical composition and mosquito larvicidal activities of the essential oils from leaves of different Cinnamonum osmophloem provenances. Journal of Agriculture and Food Chemistry, 52, 4395-4400.

Deka, M. K., sing, K., \& Handique, R. (1998). Antifeedant and repellant effects on Pongam (Pongamia pinnata) and wildsage (Lantanacamara) on tea mosquito bug (HelopeltisTheivora). Indian Journal agricultural science, 68(5), 274-276.

Dharmagadda, V. S. S., Naik, S. N., Mittal, P. K., \& Asudevan, P. (2014). Larvicidal activity of Tagetes patula essential oil against three mosquito species. Bioresource Technology, 96, 1235-1240.

Elango, G., Rahuman, A. A., Kamaraj, C., Zahir, A. A., \& Bagavan, A. (2010). Studies on effects of indigenous plant extracts on filarial vector Culex tritaeniorhynchus Giles. Parasitology Research, 107, 167-176.

Fatope, M. O., Ibrahim, H., \& Takeda, Y. (1993). Screening of higher plants reputed as pesticides using the brine shrimp lethalityassay. International Journal of Pharmacognosy, 31(2), 250-254.

Finney, J. D. (1971). Probit analysis, (3rd ed., p. 333). Cambridge: Cambridge University Press.

Gbolade, A. A., Dyedele, A. D., Sosan, M. B., Adewayin, F. B., \& Soylea, O. I. (2012) Larvicidal and knockdown effect of some essential oils against Culex quinquefasciatus say and Aedes aegypti L., and Anopheles stephensi. Advance in bioscience and. Biotechnology, 3, 855-862. 
Govindarajan, M., Mathivanan, T., Elumalai, K., Krishnappa, K., \& Anandan, K. (2011). Mosquito larvicidal, ovicidal, and repellent properties of botanical extracts against Anopheles stephensi, Aedes aegypti and Culex quinquefasciatus (Diptera: Culicidae). Parasitology Research, 109, 353-367.

Hemalatha, P., Elumalai, D., Vignesh, A., Murugesan, K., \& Kaleena, P. K. (2014). Bioefficacy of essential oil of cantana aculeate (Verbenacea) against Aedes aegypti, Anopheles stephensi and Culex quinquefasciatus. International Journal of Pure and Applied Zoology, 2320-9577.

Joshi, R. K. (2013). Chemical constituents and antibacterial property of the essential oil of the roots of Cyathocline purpurea. Journal of Ethnopharmacology, 145, 621-625.

Karthikeyan, V., Sivakumar, K., Aishwarya, G., \& Mohanasundram. (2012). Studies on larvicidal activity of Leucas aspera against Culex quinquefasciatus collected from coovem river of Chennai India; Asian Journal of Pharmacutical and Clinical Research, 0974-2441.

Kweka, E. J., Mosha, F., Lowassa, A., Mahande, A. M., Kitau, J., Matowo, J., ... Temu, E. A. (2008). Ethnobotanical study of some mosquito repellent plants in North Eastern Tanzania. Malarial Journal, 7, 152.

Liu. \& Liu. (2014). Evolution of larvicidal activity of the essential oil of Agratum conyzoides L. parts and its major constituents against Aedes albopictus Journal of Entomology and Zoology Studies, 2320-7078.

Maheswaran, R., Kingsley, S., \& Ignacimuthu, S. (2008). Larvicidal activity of Leucas aspera against the larvae of Culex quinquefasciatus say and Aedes aegypti L. International Journal of Integrative Biology, 0973-8363.

Mangathayatu, K., Amitabha, G., Rajeev, R., \& Kaushik, V. V. K. (2006). Volatile construction of Leucas aspera (Wild.) Link. Journal of Essential Oil Research, 18, 104-105.

Massebo, F., Tadesse, M., Bekele, T., Balkew, M., \& Michael, T. G. (2009). Evaluation on larvicidal effects of essential oils of some local plants against Anopheles arabiensis Patton and Aedes aegypti Linnaeus (Diptera,Culicidae) in Ethiopia. African Journal of Biotechnology, 8, 41838.

Molodchlk (2013). Leadership development. A case of a Russian business school. Middle- East Journal of Scientific Reasearch, 15(2), 222-228.

Okumu, F. O., Knols, B. G. J., \& Fillinger, U. (2007). Larvicidal effects of a neem (Azadirachta indica) oil formulation on the malaria vector Anopheles gambiae. Malaria Journal, 6, 63.

Pushpanathan, T., Jebanesan, A., \& Govindarajan, M. (2008). The essential oil of Zingifer officinalis Lin (Zingiberaceae) as a mosquito larvicidal and repellent agent against the filarial vector Culex quinquefasciatus say. Parasitology Research, 102, 1289-1291.

Rana, I. S., \& Rana, A. S. (2012). Efficacy ofessential oils of aromatic plants aslarvicidalfor the management of filarial vector Culex quinquefasciatus say (Diptera:Culicidae) with special reference to Foeniculum vulgare. Asian pacific journal tropical diseases, 2(3), 184-189.

Singh, N. P., Kumari, V., \& Chauhan, D. (2003). Mosquito larvicidal prorperties of the leaf extract of a herbaceous plant, Ocimum canum. Jonrnal of communicable diseases, 35, 43-45.

Sutthanont, N., Choochote, W., Tuetun, B., Junkum, A., Jitpakdi, A., \& Chaithong,U. (2010). Chemical composition and larvicidalactivity of edible plant-derived essential oils against the pyrethroid-susceptible and- resistant strains of Aedes aegypti (Diptera:Culicidae). Journal of vector Ecology.,35, 106-115.

Tiwary, M., Naik, S. N., Tewary, D. K., Mittal, P. K., \& Yadav, S. (2007). Chemica composition and larvicidal activities of the essential oil of Zanthoxylum aratum DC against three mosquito mosquito vectors. Journal of vector borne Disease, 44, 198-204.

WHO 1981. Instructions for Determining the Susceptibility or Resistance of Mosquito Larvae to Insecticides, WHONBC/ 81.807. Geneva: World Health Organization.

WHO (2010). World malaria report. "India". Available online, http://www.who.int/ malaria/publications/country-profiles/profile_ind_en.pdf.

\section{Submit your manuscript to a SpringerOpen ${ }^{\odot}$ journal and benefit from:}

- Convenient online submission

- Rigorous peer review

- Open access: articles freely available online

High visibility within the field

- Retaining the copyright to your article

Submit your next manuscript at $\boldsymbol{\sim}$ springeropen.com 